\title{
Pemanfaatan Tanaman Bakau Sebagai Bahan Ajar Untuk Meningkatkan Penguasaan Konsep Kimia Siswa
}

\author{
Suyanti* \\ Sekolah Menengah Pertama Seluma, Bengkulu Indonesia \\ *E-mail: suyanti.gumono@gmail.com
}

DOI: https://doi.org/10.33369/pendipa.4.3.60-69

\begin{abstract}
The aims of this research were to: 1) Identify the chemical compounds of mangrove plants (Rhizhophora mangle) with maceration technique that can be used to skin bleaching; 2) Describing of the existing "Materials Chemistry in the Life" teaching materials for the 8th grade SMP students. And continued to developing learning materials in accordance with the curriculum and learning needs of students; and 3) Describing the influences of these learning material to student achievement on chemistry? The research design was experimental research. The research started with collecting data at the laboratorium. Maceration extraction process at laboratory carried out on leaves, bark, and roots of mangrove $R$. mangle for flavonoids, alkaloids and triterpene and steroid. Extracts from R. mangle blended to make bleaching cream, with a concentration of 1\%, 2\% and 3\%. Bleaching cream from R. mangle extract, tested on male rabbit skin. Cream from R. mangle leaves, change the rabbit skin from black to dark brown. Cream of R.mangle bark, make a cream-colored rabbit skin. Meanwhile, cream from root to make the skin a light brown hare. The results of laboratory and field-testing of rabbit skin data, used to develop learning materials. Those teaching materials are used in learning activities at 8th grade SMP. At the end of the learning activities carried out an assessment. The result of normality and homogeneity test to the assessment data, showed a normal distribution and equal variance, so it is worth analyzed using $t$-test. Results of $t$-test is $=2.6011$, while $t$ table is $=$ 1.9955. Because the result of t-test is bigger than t table, then it can be concluded that the achievement of the experimental class who use teaching materials "Materials Chemistry in the Life" on learning science in class VIII A SMP 38 Seluma obtain better results than in the control class who did not use similar instructional materials in learning process.
\end{abstract}

Keywords: Chemical education, mangroves, natural skin bleaching.

\begin{abstract}
ABSTRAK
Penelitian ini bertujuan untuk 1) Mengidentifikasi senyawa kimia dalam tanaman bakau (R.mangle) dengan teknik maserasi yang dapat dimanfaatkan untuk pemutih kulit 2) Mendiskripsikan bahan ajar "Bahan Kimia dalam kehidupan" untuk siswa kelas VIII yang terdapat dipasaran saat ini dilanjutkan dengan penyusunan bahan ajar sesuai kebutuhan siswa SMP kelas VIII 3) mendiskripsikan pengaruh penggunaan bahan ajar yang telah disusun terhadap prestasi belajar siswa kelas VIII pada materi Bahan Kimia dalam Kehidupan? Desain penelitian yang diterapkan adalah penelitian eksperimen. Penelitian dimulai dari pengambilan data laboratorium. Daun, batang dan akar bakau $R$. mangle diekstraksi maserasi untuk mendapatkan senyawa flavonoid, alkaloid dan triterpen dan steroid. Ekstrak $R$. mangle dibuat krim pemutih variasi konsentrasi 1\%, 2\%, dan 3\%. Krim dari ekstrak R. mangle dicoba-ujikan pada kulit kelinci jantan yang berwarna hitam. Krim yang berasal dari daun $R$. mangle mencerahkan kulit kelinci dari hitam menjadi coklat tua. Krim dari kulit batang $R$. mangle mencerahkan kulit kelinci menjadi berwarna krem. Sedangkan krim dari akar membuat kulit kelinci berwarna coklat muda. Hasil data laboratorium dan uji-coba terhadap kulit kelinci, dimanfaatkan untuk menyusun bahan ajar "Bahan Kimia dalam Kehidupan". Bahan ajar tersebut kemudian digunakan dalam pembelajaran pada siswa kelas VIII SMP N 38 Seluma. Hasil evaluasi belajar siswa memperlihatkan bahwa data hasil belajar siswa pada kelas eksperimen dan kelas kontrol memperlihatkan sebaran data yang normal dan menunjukkan varian data yang sama, sehingga data layak dianalisis menggunakan ujit. Hasil uji t diperoleh $\mathrm{t}$ hitung 2,6011 dan $\mathrm{t}$ kritik dari tabel $\mathrm{t}$ adalah sebesar 1,9955 dikarenakan $\mathrm{t}$ hitung lebih besar dari $t$ kritik maka ada perbedaan hasil belajar kelas eksperimen (Ye) dan kelas kontrol (Yk). Dengan demikian dapat disimpulkan bahwa prestasi belajar kelompok eksperimen yang menggunakan bahan ajar "Bahan Kimia dalam
\end{abstract}


Kehidupan" pada pembelajaran IPA di kelas VIII A SMPN 38 Seluma memperoleh hasil lebih baik dari pada kelompok kontrol yang tidak menggunakan bahan ajar serupa dalam pembelajaran.

Kata kunci: Pendidikan kimia, bakau, pemutih kulit alami.

\section{PENDAHULUAN}

Kegiatan belajar mengajar IPA di SMP dirancang sebagai pembelajaran yang berdimensi pada kompetensi, sebab IPA memiliki peran penting sebagai dasar pengetahuan untuk mengungkap kejadian alam. Peningkatan mutu pendidikan berperan dalam menghasilkan peserta didik yang berkualitas. Manusia yang dapat berpikir kritis, kreatif logis dan berinisiatif dalam menanggapi isu di lingkungan kita.

Selama ini pembelajaran sains kurang berhasil meningkatkan kompetensi siswa. Model pembelajaran, materi sains, dan praktiknya sudah banyak yang dipelajari secara mendalam. Pembelajaran seperti ini sudah dijalankan tapi banyak siswa yang menganggap bahwa sains itu sulit.

Hal itu tercermin pada laporan beberapa lembaga internasional berkenaan dengan tingkat daya saing sumber daya manusia kita dengan negara-negara lain. Peringkat Human Development Index (HDI) atau kualitas sumber daya manusia Indonesia berada pada urutan 105 dari 108 negara Human Development Report (2010). Sementara itu lembaga yang mengukur hasil pendidikan Science dan Mathematics di dunia, menunjukkan bahwa siswa Indonesia berada pada urutan 35 dari 48 negara yang di survey. Kemampuan siswa Indonesia tertinggal jauh jauh di bawah negara tetangga seperti Singapura (peringkat ke 1), Malaysia (peringkat ke 21) dan Thailand (peringkat 22) Trends of International Mathematics and Science Study (TIMSS) (2011). Jumlah nilai kemampuan IPA siswa Indonesia memperoleh nilai 427, nilai tersebut terpaut jauh di bawah nilai rata-rata international 467.

Pendidikan IPA diharapkan akan membangkitkan motivasi dan kepedulian manusia terhadap lingkungan sekaligus sebagai wahana untuk memacu dan meningkatkan tanggung jawabnya terhadap lingkungan. Salah satu bentuk implementasi pendidikan lingkungan yang dapat disajikan kepada siswa SMP di Bengkulu terutama daerah pesisir adalah mengenalkan hutan mangrove yang ditumbuhi dengan tanaman bakau.

Secara umum mangrove didifinisikan sebagai vegetasi tanaman yang hidup di daerah pesisir antara garis pasang surut (pantai, laguna, muara sungai). Hutan mangrove dikenal juga dengan istilah tidal forest, coastal; woodland, vloedbosschen atau juga hutan payau. Masyarakat sering menyebut hutan mangrove dengan hutan bakau, namun karena tanaman yang tumbuh tidak hanya bakau maka dalam penelitian ini lebih banyak digunakan istilah mangrove.

Banyak ahli telah mempublikasikan temuan mereka tentang manfaat tanaman mangrove, dari berbagai aspek kehidupan. Diantara ahli tersebut antara lain: Darusman, et.al (2010), yang melakukan penelitian tentang tanaman obat-obatan pada kulit merbau (pohon api-api/Rhizophora mucronata) yang digunakan sebagai pemutih kulit. Tanaman bakau R.mangle yang memiliki habitat tempat tinggal yang sama dengan tanaman merbau yang tumbuh dihutan mangrove. Hal ini memungkinkan sifat yang sama antara tumbuhan merbau (Rhizophora mucronata) dimiliki oleh tanaman bakau jenis R.mangle untuk menghambat enzim tironase pada melanin kulit, untuk itu perlu dikaji lebih lanjut tentang pemanfaatnya R.mangle sebagai pemutih kulit.

Mempertimbangkan uraian di atas, penulis merasa perlu melakukan penelitian tentang pemanfaatan ekstrak tanaman bakau R.mangle agar dapat dimanfaatkan oleh masyarakat, misalnya sebagai bahan ajar IPA di SMP. Lebih jauh diharapkan masyarakat (khususnya siswa) dapat menjaga kelestarian hutan bakau yang ada di sekitar tempat tinggalnya.

Masalah yang akan dibahas dalam penelitian ini adalah: (1) Bagaimanakah memisahkan senyawa kimia dalam tanaman bakau (Rhizophora mangle) dengan teknik maserasi untuk dimanfaatkan sebagai pemutih kulit? (2) Bagaimanakah mendiskripsikan bahan ajar "Bahan Kimia dalam Kehidupan" untuk siswa 
SMP kelas VIII yang terdapat di pasaran saat ini dan bahan ajar ideal yang dibutuhkan siswa? (3) Bagaimanakah efektivitas penggunaan bahan ajar "Bahan Kimia dalam Kehidupan" terhadap prestasi belajar siswa SMP kelas VIII pada materi Bahan Kimia dalam Kehidupan?

\section{METODE PENELITIAN}

Populasi penelitian ini adalah siswa SMPdi SMPN di Seluma. Sampel penelitian adalah kelas VIII A dan VIII B. Kelas VIII A ditetapkan secara acak/random sebagai kelas eksperimen, sedangkan kelas VIII B menjadi kelas kontrol.

Penelitian ini dilaksanakan dengan menerapkan paradigma penelitian kuantitatif (positivistik) dan juga paradigma penelitian kualitatif (naturalistik). Implementasinya, metode penelitian yang dipakai adalah metode campuran (mixed method) yaitu kuantitatif dan kuailtatif.

Pertama paradigma kuantitatif, yaitu metode eksperimen, dimanfaatkan untuk mengolah dan menguji data-data laboratorium dan uji data-data pengaruh penggunaan modul bahan ajar di kelas subyek penelitian. Pada tahapan penelitian ini, penelitian menggunakan pendekatan deduktif, yaitu proses pengambilan kesimpulan dengan menggunakan fakta atau data empiris untuk menguji hipotesis yang telah dibangun dengan menggunakan struktur teori. Dengan kata lain, deduksi adalah proses pengambilan kesimpulan berdasarkan hasil analisis data.

Metode yang digunakan dalam penelitian ini adalah metode penelitian eksperimen dengan bentuk True Eksperimental Designs. Metode penelitian ini dipilih dengan pertimbangan dalam penelitian ini, peneliti dapat mengontrol semua variabel luar yang mempengaruhi jalannya eksperimen dilaksanakan (Sugiyono, 2007).

Kedua, paradigma kualitatif. Paradigma ini menggunakan pendekatan induksi, yaitu suatu pendekatan yang mengumpulkan data terlebih dahulu baru hipotesis dibuat jika diinginkan dan konklusi langsung diambil jika hipotesis tidak digunakan. Dengan kata lain, pendekatan induksi adalah sebagai suatu proses mengambil kesimpulan (atau pembentukan hipotesis) yang didasarkan pada satu atau lebih fakta atau buktibukti.

Paradigma kualitatif diterapkan pada tahapan penelitian perumusan modul bahan ajar
IPA dengan materi pokok Bahan Kimia dalam Kehidupan. Modul ini disusun berdasarkan kajian pustaka dan kajian kurikulum terkait materi tersebut. Selain itu, paradigma ini juga dimanfaatkan peneliti untuk menafsirkan fenomena hasil penelitian secara keseluruhan.

Pengumpulan data pada penelitian dilakukan dengan memanfaatkan dokumen dan tes. Dokumentasi ditujukan untuk menjaring data penunjang hasil belajar yang berupa nilai prestasi siswa dan hasil nilai ulangan harian. Secara detil pengumpulan data dibedakan dengan dua langkah

Teknik pengumpulan data kimia bahan alam dilaksanakan dengan langkah-langkah sebagai berikut: (1) Maserasi dengan melibatkan siswa, (2) Evaporasi, (3) Aplikasi

Langkah-langkah penelitian pada eksperimen pembelajaran menggunakan bahan ajar kimia bahan alam dikelas adalah sebagai berikut: (a) Uji Pendahuluan, (b) Pembelajaran IPA (Materi Pengenalan Bahan Kimia); (c) Eksperimen Pembelajaran.

Analisis data eksperimen pembelajaran dilakukan oleh peneliti dengan runtun pelaksanaan berturut-turut: (1) Uji Normalitas, (2) Uji Homogenitas Varians (3) Uji - t.

\section{HASIL DAN PEMBAHASAN Pengujian Sampel Bakau}

\section{A. Persiapan Data di Laboratorum}

\section{Preparasi Sampel Bakau (Rhizophora mangle)}

Langkah awal yang dilakukan adalah dengan memilih tanaman bakau yang akan diuji efektifitasnya sebagai bahan kimia pemutih kulit dan lebih lanjut dapat dimanfaatkan sebagai sumber belajar dalam pengenalan bahan-bahan kimia pada mapel IPA terpadu di SMP. Tumbuhan bakau yang digunakan dalam penelitian ini adalah tumbuhan bakau R.mangle. Bagian tanaman yang manfaatkan sebagai sampel penelitian ini adalah bagian daun, kulit batang dan bagian akar. Langkah selanjutnya adalah pembuatan simplisia dari setiap bagian tanaman bakau R.mangle. Pembuatan simplisia dengan cara diangin-anginkan, atau proses pengeringan tanpa bantuan sinar matahari. Proses pengeringan berlangsung selama 15 hari. Setelah tanaman kering kemudian di haluskan untuk memperoleh serbuk simplisia. 


\section{Pembuatan Ekstrak}

Proses untuk memperoleh senyawa yang ada pada tanaman bakau R.mangle dengan ekstraksi melalui metode maserasi dengan pelarut etanol $\left(\mathrm{CH}_{3} \mathrm{CH}_{2} \mathrm{OH}\right)$ selama 3 x 24 jam. Dipilih pelarut etanol 96\% karena etanol adalah campuran dua bahan pelarut yaitu etanol dan air dengan kadar etanol 96\% (v/v). Etanol 96\% sangat efektif dalam menghasilkan jumlah bahan aktif yang optimal serta pada saat pemisahan pelarut dengan menggunakan evaporator, dimana telah diketahui etanol mudah menguap sehingga pelarut etanol $96 \%$ akan lebih mudah pemisahan dari ekstrak.

\section{Pemisahan Ekstrak Dari Pelarut}

Ekstrak tanaman bakau yang diperoleh masih bercampur dengan pelarut etonol, untuk itu perlu dipisahkan aga memperoleh senyawa ekstrak yang bebas dari pelarut. Proses evaporasi setiap bagian tanaman bakau Rhizhophora Mangle dilakukan hingga diperoleh ekstrak murni yang kental dan bebas dari pelarut etanol. Hasil pemisahan ekstrak melalui proses eveporasi adalah sebagai berikut:

a. Ekstrak Daun Rhizhophora mangle $1500 \mathrm{ml}$ ekstrak $\rightarrow$ Evaporator $25 \mathrm{ml} \rightarrow$ senyawa hijau pekat

b. Ekstrak Kulit Batang Rhizhophora mangle $1000 \mathrm{ml}$ ekstrak $\rightarrow$ Evaporator $40 \mathrm{ml} \rightarrow$ senyawa merah pekat

c. Ekstrak akar Rhizhophora mangle $1000 \mathrm{ml}$ ekstrak $\rightarrow$ Evaporator $10 \mathrm{ml} \rightarrow$ senyawa kuning pekat

\section{Uji Kromatografi Lapis Tipis (TLC)}

Untuk mengtahui jumlah senyawa yang ada pada ekstrak yang diperoleh pada proses evaporasi maka dilakukan uji kromatografi. Identifikasi jumlah senyawa yang terdapat pada setiap ekstra tumbuhan bakau R.mangle ini dengan cara kromatografi lapis tipis (TLC).

Identifikasi jumlah senyawa yang terkandung pada setiap bagian tanaman bakau R.mangle melalui kromatografi lapis tipis dengan menggunakan lembaran tipis alumunium oksida berukuran $1 \times 10 \mathrm{~cm}$. Bagian atas diberi batas 1,5 $\mathrm{cm}$ dan bagian bawah $1 \mathrm{~cm}$ sehingga jarak tempuhnya adalah $7,5 \mathrm{~cm}$.

Eluen yang digunakan pada proses TLC ada dua jenis yaitu: a. Eluen I campuran antara: $10 \mathrm{ml}$ Etil asetat + 1,1 $\mathrm{ml}$ Asam Asetat + 2,6 $\mathrm{ml}$ Aquades

b. Eluen II campuran antara: $8,1 \mathrm{ml}$ etil asetat + 1,2 $\mathrm{ml}$ Etnol + 0,9 $\mathrm{ml}$ Aquades

\section{Uji Fitokimia}

Uji fitokimia ini didasarkan pada uji kromatografi lapis tipis (TLC) dimana pada setiap ekstrak memiliki 2 sampai 3 noda yang berarti dalam setiap ekstrak terdapat 2 hingga 3 senyawa yang berbeda.

1) Uji Flavonoid: Hasil uji kandungan senyawa flavoniod yang terdapat pada daun, akar dan batang bakau R.mangle yang dibuktikan dengan adanya endapan yang berwarna merah.

2) Uji Alkaloid: Hasil kandungan senyawa alkaloid yang terdapat pada daun, batang dan akar bakau R.mangle dapat dilihat terbentuknya endapan merah bata.

3) Uji Terpenoid :Hasil uji senyawa terpenoid daun, batang dan akar bakau R.mangle dapat dilihat dari larutan yang terbentuk larutan berwarna biru.

Berdasarkan uji fitokimia yang dilakukan terhadap ekstrak daun, ekstrak kulit batang dan ekstrak akar bakau $R$. mangle yang telah diekstrak melalui teknik maserasi menggunakan pelarut etanol $\left(\mathrm{CH}_{3} \mathrm{CH}_{2} \mathrm{OH}\right)$ mengandung senyawa flavonoid, alkaloid dan terpenoid jenis steroid dan triterpen.

\section{Pembuatan Krim (Salep)}

Krim dibuat untuk mempermudah proses pengolesan terhadap kulit sehingga mudah meresap. Krim ekstrak tanaman bakau yang telah dipisahkan dari pelarutnya dicampur dengan vaselin. Variasi perbandingan ekstrak yang dibuat krim untuk dioleskan terhadap kulit kelinci adalah $1 \%, 2 \%$ dan $3 \%$. Artinya untuk variasi $1 \%$ digunakan 1 gram ekstrak dicampur dengan 100 gram salf (vaselin), sedangkan untuk $2 \%$ digunakan 2 gram ekstrak dicampur dengan 100 gram salf dan begitu juga dengan variasi $3 \%$ digunakan 3 gram ekstrak dicampur dengan 100 g salf.

\section{Uji Aplikasi Krim Terhadap Kulit kelinci}

Untuk mengetahui efektifitas pengaruh krim ekstrak tanaman bakau sebagai bahan pemutih kulit maka perlu dilakukuan uji coba terlebih dahulu kepada kulit hewan. Hewan yang di gunakan sebagai objek penelitian ini adalah kelinci jantan yang berwarna hitam. 
Adapun hasil perubahan warna kulit kelinci yang telah diolesi dengan krim adalah sebagai berikut:

\section{Pengaruh Krim Daun Bakau Rhizhophora Mangle terhadap Kulit Kelinci}

Tabel 1. Hasil perubahan warna yang diolesi dengan krim dari daun bakau R. mangle

\begin{tabular}{|c|c|c|c|c|}
\hline \multirow{2}{*}{$\begin{array}{c}\text { Waktu } \\
\text { Perubah } \\
\text { an warna } \\
\text { kulit } \\
\text { (hari) }\end{array}$} & \multicolumn{3}{|c|}{$\begin{array}{l}\text { Konsentrasi Ekstrak Daun } \\
\text { Bakau Rhizhophora mangle }\end{array}$} & \multirow{2}{*}{ Ket } \\
\hline & $1 \%$ & $2 \%$ & $3 \%$ & \\
\hline $\begin{array}{c}1 \\
(10 / 1 / 201 \\
1)\end{array}$ & Hitam & Hitam & Hitam & $\begin{array}{l}\text { Mula- } \\
\text { mula }\end{array}$ \\
\hline 2 & Hitam & Hitam & Hitam & \\
\hline 3 & Hitam & Hitam & Hitam & \\
\hline 4 & Hitam & Memudar & Memudar & $\begin{array}{l}\text { Ada } \\
\text { bercak }\end{array}$ \\
\hline 5 & Hitam & Memudar & Memudar & \\
\hline 6 & Htam & Memudar & Memudar & \\
\hline 7 & $\begin{array}{l}\text { Memu } \\
\text { dar }\end{array}$ & Memudar & Memudar & \\
\hline 8 & $\begin{array}{l}\text { Memu } \\
\text { dar }\end{array}$ & Memudar & Abu-abu & \\
\hline 9 & $\begin{array}{l}\text { Memu } \\
\text { dar }\end{array}$ & Memudar & Abu-abu & \\
\hline 10 & $\begin{array}{l}\text { Memu } \\
\text { dar }\end{array}$ & Memudar & Abu-abu & \\
\hline 11 & $\begin{array}{l}\text { Memu } \\
\text { dar }\end{array}$ & Memudar & N0. 16 & $\begin{array}{l}\text { N0.16 } \\
\text { (Coklat } \\
\text { tua) }\end{array}$ \\
\hline 12 & $\begin{array}{l}\text { Memu } \\
\text { dar }\end{array}$ & Memudar & 16 & \\
\hline 13 & $\begin{array}{l}\text { Memu } \\
\text { dar }\end{array}$ & 16 & 16 & \\
\hline 14 & $\begin{array}{l}\text { Memu } \\
\text { dar }\end{array}$ & 16 & 16 & \\
\hline 15 & $\begin{array}{l}\text { Abu- } \\
\text { abu }\end{array}$ & 16 & 15 & $\begin{array}{l}\text { No. } 15 \\
\text { (coklat } \\
\text { muda }\end{array}$ \\
\hline 16 & $\begin{array}{l}\text { Abu- } \\
\text { abu }\end{array}$ & 16 & 15 & \\
\hline 17 & $\begin{array}{l}\text { Abu- } \\
\text { abu }\end{array}$ & 16 & 15 & \\
\hline 18 & $\begin{array}{l}\text { Abu- } \\
\text { abu }\end{array}$ & 16 & 15 & \\
\hline 19 & No. 16 & 16 & 15 & \\
\hline 20 & 16 & 16 & 15 & \\
\hline 21 & 16 & 16 & 15 & \\
\hline
\end{tabular}

Kulit kelinci yang semula berwarna hitam setelah diolesi dengan krim yang berasal dari ekstrak daun bakau rhizhopora mangle dapat berubah menjadi coklat tua atau coklat muda dengan lama waktu pegolesan adalah 21 hari. Kulit kelinci yang diolesi dengan krim berkonsentari 1\% mulai memudar setelah tujuh (7) hari pengolesan dan setelah 15 hari kulit menjadi abu-abu, pada hari ke-19 warna kulit kelinci berubah menjadi coklat muda, warna abu-abu ini tidak berubah hinngga hari ke-21.

\section{Pengaruh Krim dari Kulit Batang}

\section{Rhizhophora Mangle terhadap Kulit Kelinci}

Tabel 2. Hasil perubahan warna kulit kelinci yang diolesi dengan krim dari kulit batang

\begin{tabular}{|c|c|c|c|c|}
\hline \multirow{2}{*}{$\begin{array}{c}\text { Perubah } \\
\text { an warna } \\
\text { kulit }\end{array}$} & \multicolumn{3}{|c|}{ Konsentrasi } & \multirow{2}{*}{$\begin{array}{c}\text { Keterang } \\
\text { an }\end{array}$} \\
\hline & $1 \%$ & $2 \%$ & $3 \%$ & \\
\hline $\begin{array}{c}1 \\
(10 / 1 / 201 \\
1\end{array}$ & Hitam & Hitam & Hitam & Mula-mula \\
\hline 2 & Hitam & Hitam & Hitam & \\
\hline 3 & Hitam & Hitam & $\begin{array}{l}\text { Memud } \\
\text { ar }\end{array}$ & \\
\hline 4 & $\begin{array}{l}\text { Memud } \\
\text { ar }\end{array}$ & $\begin{array}{l}\text { Memud } \\
\text { ar }\end{array}$ & $\begin{array}{l}\text { Memud } \\
\text { ar }\end{array}$ & \\
\hline 5 & $\begin{array}{l}\text { Memud } \\
\text { ar }\end{array}$ & $\begin{array}{l}\text { Memud } \\
\text { ar }\end{array}$ & $\begin{array}{l}\text { Abu- } \\
\text { abu }\end{array}$ & \\
\hline 6 & $\begin{array}{l}\text { Memud } \\
\text { ar }\end{array}$ & $\begin{array}{l}\text { Abu- } \\
\text { abu }\end{array}$ & $\begin{array}{l}\text { Abu- } \\
\text { abu }\end{array}$ & \\
\hline 7 & $\begin{array}{l}\text { Memud } \\
\text { ar }\end{array}$ & $\begin{array}{l}\text { Abu- } \\
\text { abu }\end{array}$ & $\begin{array}{l}\text { Abu- } \\
\text { abu }\end{array}$ & \\
\hline 8 & $\begin{array}{l}\text { Abu- } \\
\text { abu }\end{array}$ & $\begin{array}{l}\text { Abu- } \\
\text { abu }\end{array}$ & No-16 & Coklat tua \\
\hline 9 & $\begin{array}{l}\text { Abu- } \\
\text { abu }\end{array}$ & N0-16 & $10-16$ & \\
\hline 10 & $\begin{array}{l}\text { Abu- } \\
\text { abu }\end{array}$ & N0-16 & N0-16 & \\
\hline 11 & N0-16 & N0-16 & N0. 15 & $\begin{array}{l}\text { N0.16 } \\
\text { (Coklat } \\
\text { tua) }\end{array}$ \\
\hline 12 & N0-16 & N0-16 & No-15 & \\
\hline 13 & N0-16 & N0-15 & N0-14 & $\begin{array}{l}\text { No-14 } \\
\text { coklat } \\
\text { kehijauan }\end{array}$ \\
\hline 14 & N0-15 & N0-14 & N0-13 & $\begin{array}{l}\text { No-13 } \\
\text { (coklat } \\
\text { muda) }\end{array}$ \\
\hline 15 & N0-14 & N0-12 & N0-12 & $\begin{array}{l}\text { No-12 } \\
\text { (coklat } \\
\text { muda) }\end{array}$ \\
\hline 16 & N0-14 & N0-12 & N0-11 & $\begin{array}{l}\text { No-11 } \\
\text { (krem) }\end{array}$ \\
\hline 17 & N0-14 & N0-11 & N0-10 & $\begin{array}{l}\text { No-10 } \\
\text { (krem } \\
\text { kehijauan) }\end{array}$ \\
\hline 18 & N0-13 & N0-10 & N0-9 & $\begin{array}{l}\text { No-9 } \\
\text { (Krem } \\
\text { muda) }\end{array}$ \\
\hline 19 & N0-12 & N0-10 & N0-9 & \\
\hline
\end{tabular}




\begin{tabular}{|c|c|c|c|l|}
\hline $\begin{array}{c}\text { Perubah } \\
\text { an warna } \\
\text { kulit }\end{array}$ & $\mathbf{4 \%}$ & $\mathbf{2 \%}$ & $\mathbf{3 \%}$ & $\begin{array}{c}\text { Keterang } \\
\text { an }\end{array}$ \\
\cline { 2 - 5 } & N0-12 & N0-9 & N0-8 & $\begin{array}{l}\text { No-8 } \\
\text { (Krem } \\
\text { muda) }\end{array}$ \\
\hline 20 & N0-10 & N0-9 & N0-7 & $\begin{array}{l}\text { No-7 } \\
\text { krem } \\
\text { keputihan })\end{array}$ \\
\hline
\end{tabular}

Penomor kulit berdasarkan grafik perubahan warna kulit dari pemutih kulit produk Garnier

Penggunaan krim yang berasal dari ekstrak kulit batang bakau $R$. mangle terhadap perubahan warna kulit kelinci terjadi begitu cepat. Krim dengan konsentrasi $1 \%$ dan $2 \%$ dapat memudarkan kulit kelinci pada penggunaan hari ke-4 sedangkan penggunaan krim dengan konsentrasi 3\% dapat memudarkan warna kulit pada hari ke-3. Pemudaran warna kulit ini tidak disertai dengan bercak-bercak warna merah.

Berdasarkan tabel di atas semakin tinggi konsentrasi krim maka semakin cepat berubahan warana kulitnya. Penggunaan krim dengan konsentrasi $3 \%$ dapat membuat kulit kelinci berwarna abu-abu dalam kurun waktu 5 hari pemakaian. Pada hari ke-8 warna kulit menjadi coklat tua, pada hari ke-11 kulit menjadi coklat muda. Perubahan ini terus berlangsung hingga pada hari ke-20 dan 21 warna kulit kelinci menjadi krem muda mendekati putih.

\section{Pengaruh Krim Akar Batang Rhzhophora Mangle terhadap Kulit Kelinci}

Tabel 3. Hasil perubahan warna kulit kelinci yang diolesi dengan krim dari akar R.mangle

\begin{tabular}{|c|c|c|c|c|}
\hline \multirow{2}{*}{$\begin{array}{c}\text { Peruba } \\
\text { han } \\
\text { warna } \\
\text { kulit }\end{array}$} & \multicolumn{3}{|c|}{ Konsentrasi } & \multirow[b]{2}{*}{$\begin{array}{l}\text { Ketera } \\
\text { ngan }\end{array}$} \\
\hline & $1 \%$ & $2 \%$ & $3 \%$ & \\
\hline $\begin{array}{c}1 \\
(10 / 1 / 20 \\
11)\end{array}$ & Hitam & Hitam & Hitam & $\begin{array}{l}\text { Mula- } \\
\text { mula }\end{array}$ \\
\hline 2 & Hitam & Hitam & Hitam & \\
\hline 3 & Hitam & Hitam & Hitam & \\
\hline 4 & Hitam & Memudar & Memudar & $\begin{array}{l}\text { Ada } \\
\text { bercak }\end{array}$ \\
\hline 5 & Memudar & Memudar & Memudar & \\
\hline 6 & Memudar & Memudar & Abu-abu & \\
\hline 7 & Abu-abu & Abu-abu & Abuabu & \\
\hline 8 & Abu-abu & Abu-abu & No-16 & $\begin{array}{l}\text { No-16 } \\
\text { (Coklat } \\
\text { tua) }\end{array}$ \\
\hline
\end{tabular}

\begin{tabular}{|c|c|c|c|c|}
\hline \multirow{2}{*}{$\begin{array}{c}\text { Peruba } \\
\text { han } \\
\text { warna } \\
\text { kulit }\end{array}$} & \multicolumn{3}{|c|}{ Konsentrasi } & \multirow{2}{*}{$\begin{array}{l}\text { Ketera } \\
\text { ngan }\end{array}$} \\
\hline & $1 \%$ & $2 \%$ & $3 \%$ & \\
\hline 9 & Abu-abu & No-16 & No-16 & \\
\hline 10 & Abu-abu & No-16 & No-15 & $\begin{array}{l}\text { N0.15 } \\
\text { (Coklat } \\
\text { muda) }\end{array}$ \\
\hline 11 & Abu-abu & No-16 & N0. 15 & \\
\hline 12 & Abu-abu & No-16 & No-14 & $\begin{array}{l}\text { No-14 } \\
\text { (coklat } \\
\text { kehijau } \\
\text { an) }\end{array}$ \\
\hline 13 & No-16 & No-15 & No-14 & \\
\hline 14 & No-16 & No-14 & No-13 & $\begin{array}{l}\text { No-13 } \\
\text { (Coklat } \\
\text { muda) }\end{array}$ \\
\hline 15 & No-16 & No-14 & No-13 & \\
\hline 16 & No-16 & No-14 & No-13 & \\
\hline 17 & No-16 & No-14 & No-12 & $\begin{array}{l}\text { No-12 } \\
\text { (coklat } \\
\text { tua) }\end{array}$ \\
\hline 18 & No-15 & No-13 & No-12 & \\
\hline 19 & No-15 & No-13 & No-11 & $\begin{array}{l}\text { No- } \\
11(\text { cokl } \\
\text { at } \\
\text { muda) }\end{array}$ \\
\hline 20 & No-14 & No-12 & No-11 & \\
\hline 21 & No-14 & No-12 & No-10 & $\begin{array}{l}\text { No-10 } \\
\text { (coklat } \\
\text { muda) }\end{array}$ \\
\hline
\end{tabular}

Penomor kulit berdasarkan grafik perubahan warna kulit dari pemutih kulit produk Garnier

Krim yang terbuat dari ekstrak akar bakau R.mangle dengan variasi konsentrasi $1 \%$, $2 \%$ dan $3 \%$ dan dioleskan terhadap kulit kelinci selama 21 hari. Penggunaan krim dengan konsentrasi $1 \%$ dapat memudarkan warna kulit kelinci setelah pemakaian hari ke-5. Pemudaran warna kulit ini disertai dengan bercak-bercak merah atau peradangan kulit.

Krim yang berkonsentrasi 3\% dapat memudarkan kulit kelinci setelah 4 hari pegolesan namun pemudaran warna kulit ini disertai dengan timbulnya bercak-bercak merah atau peradangan kulit. Warna kulit kelinci menjadi abu-abu setelah waktu pengolesan hari ke-6, pada saat pengolesan memasuki hari ke-8 warna kulit kelinci menjadi coklat tua. Perubahan warna kulit ini terus berlangsung hingga pada hari ke-21 pengolesan warna kulit kelinci menjadi coklat muda.

\section{Pengaruh Krim Pemutih yang Beredar di Pasaran (Krim Blanko) terhadap Kulit}




\section{Kelinci}

Tabel 4. Hasil pengolesan kulit kelinci menggunakan krim blanko

\begin{tabular}{|c|c|c|}
\hline $\begin{array}{l}\text { Waktu Perubahan } \\
\text { warna kulit (hari) }\end{array}$ & $\begin{array}{c}\text { Perubahan } \\
\text { Warna Kulit }\end{array}$ & Keterangan \\
\hline $1(10 / 1 / 2011)$ & Hitam & Mula-mula \\
\hline 2 & Hitam & \\
\hline 3 & Hitam & \\
\hline 4 & Hitam & \\
\hline 5 & Memudar & $\begin{array}{l}\text { Bercak-bercak } \\
\text { pengelupasan } \\
\text { kulit }\end{array}$ \\
\hline 6 & Memudar & \\
\hline 7 & Kulit pucat & $\begin{array}{l}\text { Pegelupasan } \\
\text { kulit }\end{array}$ \\
\hline 8 & Kulit pucat & \\
\hline 9 & Kulit pucat & \\
\hline 10 & Kulit pucat & \\
\hline 11 & Kulit pucat & \\
\hline 12 & Kulit merah & $\begin{array}{l}\text { Kulit } \\
\text { meradang, } \\
\text { kulit luar lepas }\end{array}$ \\
\hline 13 & Kulit merah & \\
\hline 14 & Kulit merah & \\
\hline 15 & Kulit merah & \\
\hline 16 & Kulit merah & \\
\hline 17 & Kulit merah & \\
\hline 18 & $\begin{array}{l}\text { Merah bercak } \\
\text { putih }\end{array}$ & $\begin{array}{l}\text { Warna putih } \\
\text { tdak merata }\end{array}$ \\
\hline 19 & $\begin{array}{l}\text { Merah bercak } \\
\text { putih }\end{array}$ & \\
\hline 20 & $\begin{array}{l}\text { Merah bercak } \\
\text { putih }\end{array}$ & \\
\hline 21 & $\begin{array}{l}\text { Merah bercak } \\
\text { putih }\end{array}$ & \\
\hline
\end{tabular}

Penomor kulit berdasarkan grafik perubahan warna kulit dari pemutih kulit produk Garnier

Krim blanko yang digunakan tidak bervariasi konsentrasi. Krim blanko dapat memudarkan warna kulit kelinci setelah pengolesan selama 5 hari, pemudaran ini disertai dengan bercak-bercak dan pegelupasan kulit kelinci sehingga kulit kelinci menjadi pucat setelah dioleskan selama 11 hari. Pada hari ke-12 kulit kelinci menjadi merah disertai dengan bercak-bercak putih, kejadian ini terus terjadi hingga hari ke-21.

Dengan demikian dapat dilihat bahwa senyawa kimia yang terkandung dalam tumbuhan bakau R.mangle yang diambil melalui proses kimia maserasi, dapat digunakan sebagai pemutih pada kulit kelinci.

\section{B. Pembuatan Bahan Ajar}

\section{Deskripsi Bahan Ajar IPA \\ Bahan Ajar yang Tersedia}

Setiap buku teks pelajaran diharapkan memenuhi standar-standar tertentu. Standar yang dimaksud meliputi persyaratan, karakteristik, dan kompetensi minimum yang harus terkandung di dalam suatu buku pelajaran. Standar penilaian dirumuskan dengan melihat tiga aspek utama, yaitu kelayakan isi, penyajian, bahasa/keterbacaan, dan kegrafikaan (BSNP. 2010: 9-12).

Telaah terhadap bahan ajar "Bahan Kimia dalam Kehidupan" pada buku Belajar IPA Membuka Cakrawala Alam Sekitar 2 untuk kelas VIII SMP/MTs menghasilkan poin 87, sedangkan buku IPA TERPADU, Jilid II kelas VIII SMP menghasilkan skor 84, dan buku ketiga IPA Terpadu untuk SMP dan MTs menghasilkan skor 86 . Tiga buku teks di atas memperlihatkan bahwa ketiganya layak digunakan sebagai bahan ajar dengan kategori "Baik".

Namun demikian, buku teks-buku teks tersebut, menurut penulis belum mencukupi kebutuhan belajar anak. Kekurangan yang menonjol dari bahan ajar yang tersedia menurut analisis peneliti adalah bahan ajar yang ada belum cukup menstimulasi siswa untuk aktif menyelidiki sumber daya alam di lingkungannya. Bahan kimia baik alamiah ataupun sintetis, yang dikenalkan lebih berupa pengetahuan mengenai produk-produk jadi yang mungkin digunakan sehari-hari oleh siswa atau masyarakat di lingkungannya. Bahan kimia yang diperkenalkan dalam buku misalnya, za-zat kimia yang terdapat dalam produk pembersih, pemutih, pewangi, pestisida, zat aditif makanan, zat adiktif, dan psikotropika.

\section{Uji Pakar Bahan Ajar}

Bahan ajar "Bahan Kimia dalam Kehidupan" sebelum digunakan dalam pembelajaran IPA, terlebih dahulu dianalisis oleh tim pakar yang terdiri dari dua orang guru inti dan satu orang dosen. Menurut tim pakar bahan ajar "Bahan Kimia dalam Kehidupan" dari segi:

\section{Kelayakan Isi}

Keluasan materi sudah memenuhi substansi minimal (fakta, konsep, prinsip dan teori) yang terkandung dalam Standar Kompetensi dan Kompetensi Dasar. Materi yang 
disampaikan sesuai dengan ranah kognitif, afektif dan psikomotorik yang dituntut SK/KD. Materi yang disampaikan sesuai dengan kebenaran fakta, konsep dan prinsip dan teori IPA dan tidak menimbulkan banyak tafsiran selain itu materinya kontekstual dan salingtemas (Sains, Lingkungan, Teknologi dan Masyarakat).

\section{Kelayakan Penyajian}

Penyajian materi dalam bahan ajar urut dimana konsep dasar yang sederhana terlebih dahulu disampaikan sebelum konsep yang lebih rumit, penyajian setiap bab sesuai dengan sistematika penulisan dan uraian substansi bab proporsional dengan mempertimbangkan SK/KD. Penyaijian materi dalam buku bersifat interaktif dan partisipasif sehingga memotivasi peserta didik untuk belajar mandiri, menekankan pada keterampilan proses sehingga aman digunakan peserta didik dan menggunakan berbagai metode gar tidak bosan yang lebih penting penyajian bahan ajar tersebut menyajikan pembelajaran terpadu yang mencakup materi Kimia, Biologi dan Fisika.

\section{Kelayakan Bahasa}

Bahan ajar "Bahan Kimia dalam Kehidupan" menggunakan bahasa yang sederhana, menarik, lugas dan mudah dipahami. Bahasa yang digunakan sesuai dengan kematangan sosial dan emosional peserta didik sehingga menimbulakn rasa senang pada peserta didik dan mendorong mereka untuk mempelajari buku secara tuntas. Istilah-istilah yang digunakan sesuai dengan kamus bahasa indonesia untuk tingkat SMP dan sesuai dengan istilah yang disepakati dalam IPA dan digunakan secara konsisten. Bahan ajar "Bahan Kimia dalam kehidupan" yang digunakan di kelas VIII sudah memenuhi substansi.

\section{Uji Pengaruh Bahan Ajar terhadap Prestasi Belajar}

Efektifitas penggunaan bahan ajar diukur dari pencapaian prestasi belajar siswa. Prestasi belajar yang dimaksud dalam penelitian ini adalah nilai yang didapat siswa setelah menempuh materi "Bahan Kimia dalam Kehidupan" dan ditunjukan dengan nilai angka. Untuk mendapatkan nilai prestasi belajar, peneliti menganalisis data nilai pre tes dan nilai pos test yang diperoleh siswa.

Jumlah sampel tiap-tiap kelompok (kelas) sebanyak 35 , adapun artinya jumlah $(\Sigma)$ nilai pre test pada kelompok eksperimen sebesar 1733.33, dan post test sebesar 2540.70. Pada kelas kontrol memiliki jumlah yang sama yaitu 35 siswa pada jumlah $(\Sigma)$ nilai pre test pada kelompok kontrol sebesar 1744,44, dan post test sebesar 2366,67. Adanya data dari dua kelas yaitu kelas eksperimen dan kelas kontrol maka terlebih dahulu dilakukan uji Normalitas data dari setiap kelas hal ini bertujuan untuk mengetahui sebaran data yang ada pada kedua kelas tersebut.

Hasil uji Normalitas kelas eksperimen dan kelas kontrol adalah seperti pada tabel berikut:

Tabel 5. Hasil Uji Normalitas

\begin{tabular}{|l|l|l|l|l|}
\hline Kelompok & N & $\begin{array}{l}\text { D } \\
\text { hitung }\end{array}$ & $\begin{array}{l}\text { D } \\
\text { tabel }\end{array}$ & Keterangan \\
\hline $\begin{array}{l}\text { Kelas } \\
\text { Eksperim. (Ye) }\end{array}$ & 35 & 0,1973 & 0,230 & Normal \\
\hline $\begin{array}{l}\text { Kelas Kontrol } \\
\text { (Yk) }\end{array}$ & 35 & 0,1477 & 0,230 & Normal \\
\hline
\end{tabular}

Berdasarkan tabel kelas Eksperimen (Ye) memiliki D hitung lebih kecil dari D tabel maka data terdistribusi normal atau dengan kata lain data hasil belajar kelompok eksperimen memenuhi syarat normalitas. Pada kelas kontrol D hitung juga lebih kecil dibanding dengan D tabel maka data terdistribusi normal dengan kata lain kelas kontrol memenuhi syarat normalitas. Dengan demikian kelas eksperimen dan kelas kontrol memenuhi syarat normalitas karena data hasil belajar terdistribusi dengan normal.

Untuk mengetahui Homogenitas Varians kelas eksperimen dan kelas kontrol maka dilakukan uji F. Hasil analisis uji homogenitas varians dapat dilihat pada tabel berikut:

Tabel 6. Hasil Uji Homogenitas Varians

\begin{tabular}{|l|l|l|l|l|}
\hline Kelompok & $\mathbf{N}$ & $\sum \mathbf{Y}$ & $\sum \mathbf{Y}^{\mathbf{2}}$ & $\mathbf{S}^{\mathbf{2}}=$ varian \\
\hline $\begin{array}{l}\text { Kelas } \\
\begin{array}{l}\text { Eksperimen } \\
(\text { Ye })\end{array}\end{array}$ & 3 & $\begin{array}{l}2540 \\
.72\end{array}$ & $\begin{array}{l}186443 . \\
6272\end{array}$ & 59.0494 \\
\hline $\begin{array}{l}\text { Kelas Kontrol } \\
(\mathrm{Yk})\end{array}$ & 3 & $\begin{array}{l}2366 \\
.68\end{array}$ & $\begin{array}{l}162374 . \\
8864\end{array}$ & 68.8629 \\
\hline
\end{tabular}


Berdasarkan tabel hasil $\mathrm{F}$ hitung adalah 1,1662 dan $F$ tabel 1,7721 karena $F$ hitung lebih kecil dari $\mathrm{F}$ tabel maka varians tidak berbeda atau kelas eksperimen dan kelas kontrol mempunyai varians yang sama atau homogen.

Langkah selanjutnya adalah dengan melakukan uji t-test data untuk kelas eksperimen dan kelas kontrol. Analisis data menggunakan uji t-test dapat dilihat pada tabel berikut.

Tabel 7. Hasil Uji T-test

\begin{tabular}{|l|l|l|l|}
\hline Kelompok & $\mathbf{N}$ & $\overline{\mathbf{X}}$ & $\mathbf{S}^{\mathbf{2}}$ \\
\hline $\begin{array}{l}\text { Kelas } \\
\text { Eksperimen (Ye) }\end{array}$ & 35 & 72.592 & 59.0494 \\
\hline $\begin{array}{l}\text { Kelas Kontrol } \\
(\text { Yk) }\end{array}$ & 35 & 67.6194 & 68.8629 \\
\hline
\end{tabular}

Hasil perhitungan uji $\mathrm{t}$ diperoleh $\mathrm{t}$ hitung 2,6011 dan $\mathrm{t}$ kritik dari tabel $\mathrm{t}$ adalah sebesar 1,9955 dikarenakan $\mathrm{t}$ hitung lebih besar dari $\mathrm{t}$ kritik maka ada perbedaan hasil belajar kelas eksperimen (Ye) dan kelas kontrol (Yk). Dari tabel 4.18 rata-rata kelas eksperimen lebih tinggi dari rata-rata kelas kontrol maka hasil belajar kelas eksperimen lebih baik dari kelas kontrol.

Memperhatikan perhitungan di atas, dapat disimpulkan bahwa prestasi belajar kelompok eksperimen yang menggunakan bahan ajar "Bahan Kimia dalam Kehidupan" pada pembelajaran IPA di kelas VIII A SMPN 38 Seluma memperoleh hasil lebih baik dari pada kelompok kontrol yang tidak menggunakan bahan ajar serupa dalam pembelajaran.

\section{KESIMPULAN \\ Kesimpulan}

Kesimpulan yang diperoleh dari penelitian ini adalah:

1. Senyawa kimia yang terkandung di dalam daun, kulit batang dan akar tumbuhan bakau Rhizhophora mangle adalah senyawa flavonoid, alkaloid dan terpenoid jenis steroid dan triterpen. Senyawa-senyawa kimia yang terkandung dalam kulit batang bakau R.mangle mampu mencerahkan kulit kelinci menjadi berwarna krem, sedangkan yang berasal dari daun dan kulit akar dapat menjadikan kulit kelinci berwarna coklat muda.
2. Hasil evaluasi bahan ajar yang terdapat di pasaran saat ini, yang membahas materi "Bahan Kimia dalam Kehidupan" untuk siswa SMP kelas VIII sudah tergolong baik atau layak untuk digunakan dalam proses belajar mengajar, namun belum cukup menstimulasi siswa untuk aktif menyelidiki sumber daya alam di lingkungan.

3. Penggunaan bahan ajar "Bahan Kimia dalam Kehidupan" mampu meningkatkan prestasi belajar siswa kelas VIII pada materi Bahan Kimia dalam Kehidupan.

\section{Saran}

1. Penelitian tentang bakau Rhizophora mangle sebagai salah satu bahan pencerah kulit perlu dikembangkan lebih lanjut untuk kepantingan manusia.

2. Dilakukan kajian lebih mendalam tentang bahan ajar yang dapat menstimulasi siswa untuk aktif menyelidiki sumber daya alam dilingkungannya.

3. Perlu kajian lebih lanjut tentang bahan ajar "Bahan Kimia dalam Kehidupan" untuk meningkatkan prestasi belajar siswa.

\section{DAFTAR PUSTAKA}

Abdul Majid. 2005. Perencanaan Pembelajaran (Bandung: Penerbit PT Remaja Rosdakarya.

Arikunto, S. 2002. Prosedur Penelitian Suatu Pendekatan Praktek Edisi Revisi V. Jakarta: PT. Rineka Cipta.

Badan Nasional Standar Pendidikan. 2010. Laporan BSNP 2009. Jakarta: BSNP

OECD. 2003. Chapter 3 of the Publication "PISA 2003 Assesment of framework mathematics, Reading, Science and problem solving knowledge and skills. http://www.oecd.org /dataoecd/38/29/33707226.pdf.

Darliana. 2005. Pendekatan Fenomena Mengatasi Kelemahan Pembelajaran IPA. http://www.p4tkipa.org.

Departemen Pendidikan Nasional. 2007. Naskah Akademik Kajian kebijakan Kurikulum Mata Pelajaran IPA. Pusat Kurikulum Badan penelitian dan Pengembangan Departemen pendidikan nasional. 
Firman, H. 2007. Analisis Literasi Sains Berdasarkan Hasil PISA Nasional Tahun 2006. Jakarta: Pusat Penilaian Pendidikan Balitbang Depdiknas.

Purwadi, B. 2006. PISA dan TIMSS 2003. Gambaran Umum Metode Penelitian. Jakarta: Puspendik Depdiknas.

PISA. 2010. Science Competencies for Tomorrow's World Volume 1-analysis. OECD. www.oecd.org/statistics/statlink.
Pusat Perbukuan Depdiknas. 2009. Standar Penilaian Buku Pelajaran Sains. http/www.dikdaski.go.id.

Young. 2005. Melanogenesis: a photoprotective response to DNA damage. Merrill, an imprint of Macmillan Colege Publishing Company. 